\title{
Zircon Trace Element Geochemistry and Ti-in-Zircon Thermometry of the Ngazi-Tina Pan-African Post-Collisional Granitoids, Adamawa Cameroon
}

\author{
Alexis Hamdja Ngoniri1, Habib Dadjo Djomo ${ }^{2}$, Timoleon Ngnotue ${ }^{1}$, Patrick Ayonta Kenne ${ }^{1}$, \\ Ghislain Ngassam Mbianya1, Sylvestre Ganno ${ }^{3 *}$, Jean Paul Nzenti ${ }^{3}$
}

${ }^{1}$ Department of Earth Sciences, University of Dschang, Dschang, Cameroon

${ }^{2}$ Institute for Geological and Mining Researches (IGMR), Yaounde, Cameroon

${ }^{3}$ Department of Earth Sciences, University of Yaoundé I, Yaounde, Cameroon

Email: ^tngnotue@yahoo.fr, ^sganno2000@gmail.com

How to cite this paper: Ngoniri, A.H., Djomo, H.D., Ngnotue, T., Kenne, P.A., Mbianya, G.N., Ganno, S. and Nzenti, J.P. (2021) Zircon Trace Element Geochemistry and Ti-in-Zircon Thermometry of the Ngazi-Tina Pan-African Post-Collisional Granitoids, Adamawa Cameroon. International Journal of Geosciences, 12, 307-328. https://doi.org/10.4236/ijg.2021.124017

Received: February 25, 2021

Accepted: April 12, 2021

Published: April 15, 2021

Copyright $\odot 2021$ by author(s) and Scientific Research Publishing Inc. This work is licensed under the Creative Commons Attribution International License (CC BY 4.0).

http://creativecommons.org/licenses/by/4.0/

(c) (i) Open Access

\begin{abstract}
In Cameroon, the Ngazi-Tina region belongs to the Adamawa-Yade domain of the Pan-African Central African Fold Belt (CAFB). It is composed of two petrographic types: quartz-monzonites (majority) and nepheline syenites. Two morphological types, prismatic and pyramidal, were recognized in the zircon grains samples. These zircon types display internal structures typical of magmatic zircons. Zircons separated from the Ngazi-Tina samples contain higher abundances of $\mathrm{Hf}$ (close to $8000 \mathrm{ppm}$ ) and moderate trace elements $(\mathrm{Y}, \mathrm{Th}, \mathrm{U}, \mathrm{Nb}, \mathrm{Ta})$ and REE contents, suggesting a variable degree of magmatic evolution. The chondrite-normalized REE patterns of zircons are characterized by LREE depletion relative to HREE with positive Ce and negative $\mathrm{Eu}$ anomalies, typical of magmatic zircons. The high $\mathrm{Hf}$ content together with high $\mathrm{Ce} / \mathrm{Ce}^{*}, \mathrm{Th} / \mathrm{U}, \mathrm{Zr} / \mathrm{Hf}$ ratios suggest magma crystallization under variable oxidation and oxygen fugacity. The application of Ti-in-zircon thermometer reveals crystallization temperatures ranging from $678^{\circ} \mathrm{C}$ to $811^{\circ} \mathrm{C}$ and $658^{\circ} \mathrm{C}$ to $768^{\circ} \mathrm{C}$ for quartz monzonites and nepheline syenites respectively. These features indicate probably a partial melting of continental crust as the source of these zircons grains and emplacement in the magmatic-arc setting.
\end{abstract}

\section{Keywords}

Granitoids, Zircon Geochemistry, Ti-in-Zircon Thermometer, Continental Crust, Ngazi-Tina, Adamawa-Yade Cameroun 


\section{Introduction}

Pan-African orogeny contributed to the formation and recycling of continental crust during the melting of Gondwana from 870 to $550 \mathrm{Ma}$ ([1] [2]). This Pan-African orogeny generated granitoids with different chemical compositions and evolutionary processes, in various tectonic environments [3]. In Cameroon, three main geological domains have recorded the Pan-African orogeny imprints (Figure 1). The Adamawa-Yadé domain is characterized by widespread syn- to post-collisional granitoids of Neoproterozoic in age ([4] [5] [6]). During the past two decades, these granitoids have been studied in order to better understand the geodynamic evolution of this orogenic belt, which generally involve collision processes between continents ([7]-[12]) However, except recent works ([13] [14]), these studies do not integrate the trace element composition of zircon as well as the temperatures of the magma in which these zircons were crystallized. Here, we examine the morphology, internal structure, trace elements and Ti-inzircon thermometer of zircon grains extracted from Ngazi-Tina rocks with the aim to clarify the origin and nature of magma, and to better constraint the tectonic setting.

\section{Geological Setting}

The Central African Fold Belt (CAFB; [15] [16] [17]) or North Equatorial Pan-African Fold Belt [18] is a huge domain of the Pan-African orogeny [19], limited to the northwest by the Trans-Saharan belt, to the south by the Congo Craton, and extends west to northeast Brazil by the Sergipano Belt, thus forming the Pan-African-Braziliano Belt ([20] [21] [22]). The latter results from the collision between large continental blocks: the West African/São Francisco cratons, the Congo craton, and an intermediate Neoproterozoic age domain, which includes the polycyclic basement provinces of Hoggar, Nigeria and Borborema (Figure 1(a)).

In Cameroon, the CAFB is mostly formed of Precambrian rocks. It extends from the Yaoundé Group (YD) in the south to the Western Cameroon Domain (WCD) in the Far North of Cameroon [20]. This belt, formed between $1122 \mathrm{Ma}$ (U-Pb age on zircon; [21]) and $558 \mathrm{Ma}$ (EMP age; [22]), has been subdivided into three domains ([14] [23]): the West Cameroon Domain (WCD) in the north, the Adamawa-Yade Domain (AYD) in the center and the Yaounde Domain (YD) in the south (Figure $1(\mathrm{~b})$ ).

The AYD is composed mainly of metamorphic basement rocks intruded by granitoids ([4] [20] [24] [25] [26] [27]). The metamorphic rocks comprised schists, amphibolites and gneisses. Their U-Pb zircon dating has revealed late Archean to Paleoproterozoic protolith ages and Pan-African metamorphic age ([26] [28] [29] [30]). The granitic rocks (granites, granodiorites, quartz monzonites, monzodiorites) are metaluminous to weakly peraluminous. Most of these granitoids are hyper-potassic with calc-alkaline to shoshonitic affinity. They show signatures of I-type granites ([5] [6] [31] [32] [33] [34]). The granitoids of the 


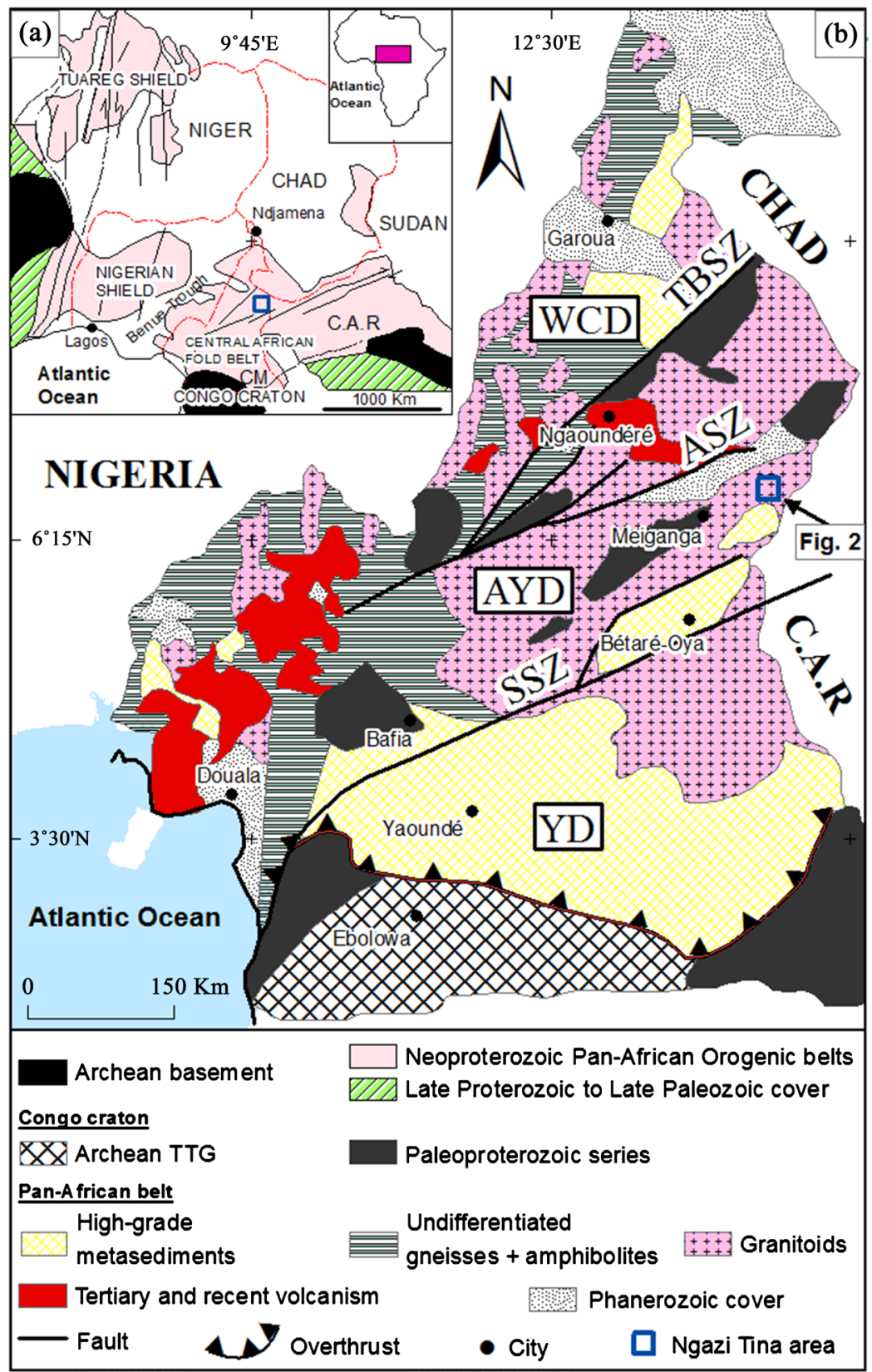

Figure 1. (a) Geological sketch map of West-Central Africa and Northeast Brazil with cratonic masses and the Pan-African-Brasiliano belts in West Gondwana (modified from [4]); (b) Geological map of Cameroon showing the major lithotectonic domains. WCD: West Cameroon Domain, AYD: Adamawa-Yadé Domain, YD: Yaoundé Domain, TBSZ: Tcholliré-Banyo Shear Zone, ASZ: Adamawa Shear Zone, SSZ: Sanaga Shear Zone. Location of study area is marked by a blue square.

Adamawa-Yade Domain are Neoproterozoic in age ([11] [35] [36] [37] [38]).

The Ngazi-Tina area belongs to the eastern part of the AYD at the border with the Central African Republic (CAR). This area comprises both granitoids and metamorphic rocks ([27] [39]). The granitoids are composed of granites, syenites and diorites, both showing metaluminous and I-type signatures. However the diorites are ferroan and high-K calc-alkaline while the granites and syenites 
are magnesian and shoshonitic. LA-ICP-MS U-Pb zircon analyses yield emplacement age of $576.4 \pm 1.9 \mathrm{Ma}$ (granites) and $585.9 \pm 2.1 \mathrm{Ma}$ (syenites) [39]). The metamorphic rocks are meta-igneous (gneisses, amphibolites) and meta-sedimentary (schists) rocks (Figure 2 ). These basement rocks are locally covered by Cenozoic volcanic rocks of the Cameroon Volcanic Line [5] and by Cretaceous deposits.

\section{Analytical Methods}

Samples were collected from fresh outcrops in Mount Tina. Two samples (quartz-monzonite, NGT 28 and nepheline syenite, NGT 23) were selected for zircon analyses. Zircon grains were extracted from each sample using conventional gravimetric and magnetic techniques, following by handpicking under a binocular microscope at Langfang Rock Detection Technology Services Ltd (Hebei, China). Then, all subsequent zircon treatment was conducted at Beijing Kehui Testing International Co. Ltd (Beijing, China) ([40] [41]). The representative zircon grains were mounted on an epoxy resin and polished to mid-section to expose their cores for analyses ([9] [40] [41] [42]). The scanning electron microscope JSM 6510, attached to a Gatan CL detector with a voltage of $10 \mathrm{kv}$, was used to produce microphotographs in transmitted and reflected light, and cathodoluminescence (CL) images. Zircon trace elements and U-Th-Pb analyses on zircon were performed using an ESI NWR $193 \mathrm{~nm}$ laser ablation system and an ICP-MS Anlyitik Jena PQMS Elite instrument. These analyses were performed with a beam diameter of $30 \mu \mathrm{m}$, a repetition frequency of $10 \mathrm{~Hz}$, and an

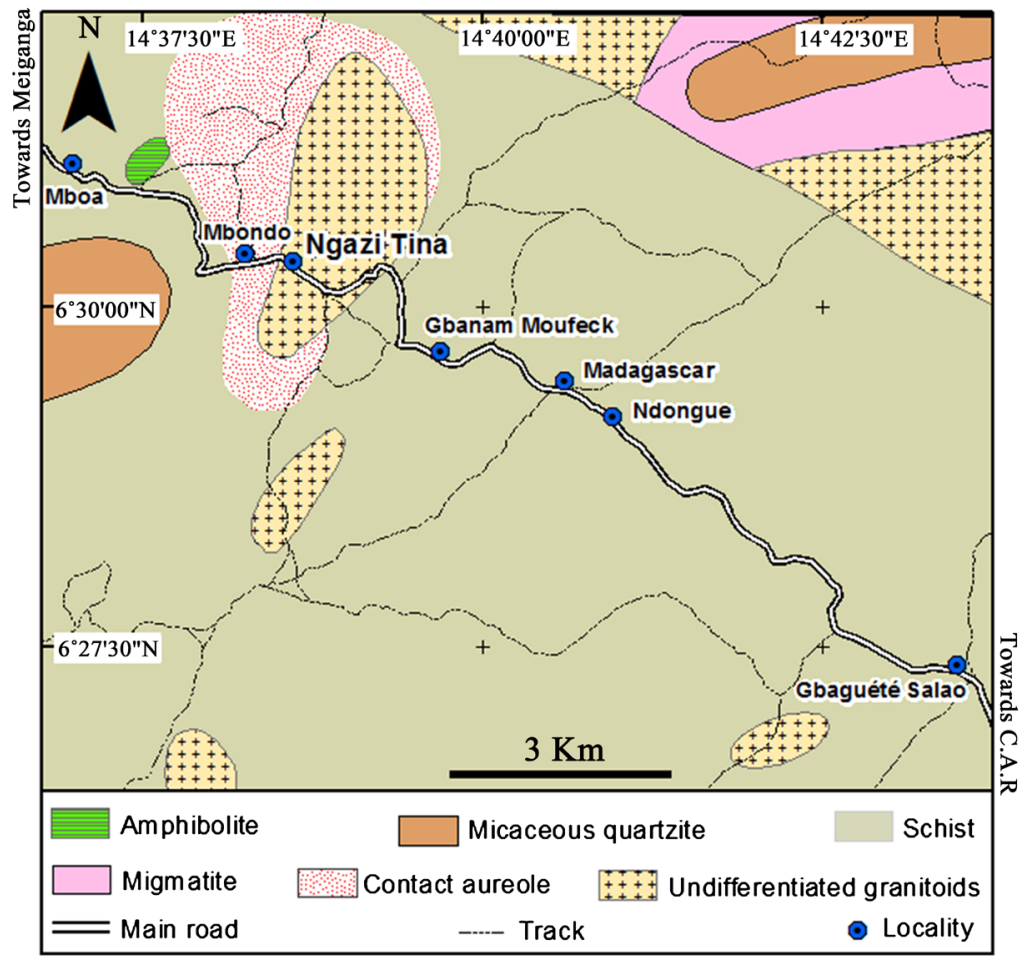

Figure 2. Geological map of the Ngazi-Tina area [27]. 
energy of $4 \mathrm{~J} / \mathrm{cm}$. The standards used for each series of 5 to 10 analyses are 91500 zirconia, GJ-1 glass, Plesovice, Qinhu and NIST610 ([9] [41] [43] [44]).

\section{Results}

Fifty-five spots were obtained on zircon grains, including 29 for quartz monzonites and 26 for nepheline syenites. Cathodoluminescence (CL) images were used for spot selection during trace element analyses, and to describe the external shape (morphology) and their internal structure.

\subsection{Zircon Morphology}

Quartz-monzonite zircons display both prismatic and pyramidal shapes. The prismatic zircons are euhedral with a size ranging from $50 \times 40$ to $180 \times 60 \mu \mathrm{m}$ and axial ratios between 2:1 and 3:1 (Figure 3(a)). The pyramidal zircons are subeuhedral in shape. They are quite smaller compare to prismatic zircons, ranging from 30 to $120 \mu \mathrm{m}$ in length (Figure 3(a)). The length/width ratio gives values of 1:1 and 2:1. Zircons from nepheline syenite sample also exhibit pyramidal and prismatic shapes, similar to those of quartz-monzonite. The prismatic shape is the more abundant type, displays size ranging from $40 \times 30$ to $105 \times 50$ $\mu \mathrm{m}$ with an average axial ratio of 2:1 (Figure 3(b)). Pyramidal-shape zircons show a variable size with average length to width ratio of 2:1 (Figure 3(b)). Both nepheline syenite and quartz-monzonite shared fine grains zircons and sometimes truncated zircons (Figure 3(a) and Figure 3(b)).

\subsection{Zircons Microstructure}

In $\mathrm{CL}$ images, the studied zircon grains are light to light brown in color. They

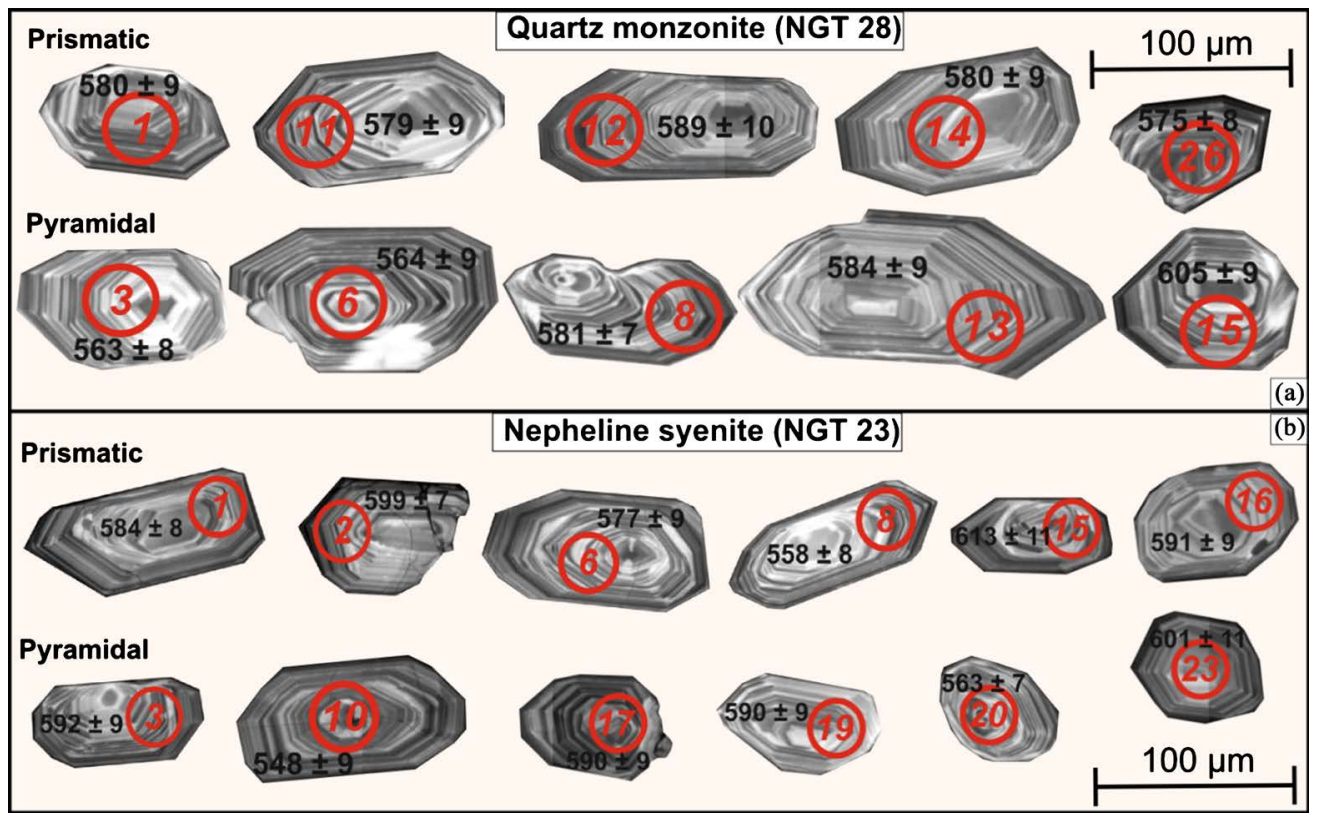

Figure 3. Cathodoluminescence (CL) images of zircon grains from the Ngazi-Tina granitoid (Laser ablation spots and number indicated in red. Ages indicated in black). 
show regular concentric zoning, characterized by light and dark bands (Figure 3(a)). This feature is typical of zircon grew in magmatic environment ([41] [45] [46]). In a few grains, the internal parts display many inclusions which were avoided during analysis. No relic's core and metamictisation have been found within the studied samples. Fractures are visible in some nepheline syenite zircon grains, whereas they are rare in quartz-monzonite zircons. Overall, CL images of the zircons from Ngazi-Tina granitoids indicate a single crystallization episode with no evidence for either later metamorphism or inheritance of earlier grains.

\subsection{Zircon Geochemistry}

Trace elements and rare earth elements (REE) composition of fifty-five individual zircon grains are listed in Table 1 and Table 2. The REE were normalized to chondrite, with the normalization values for chondrite being taken from [47].

Trace elements of the two samples vary significantly between grains in the same sample. The $\mathrm{U}$ and Th content vary from 72.02 to $215.76 \mathrm{ppm}$ (average $125.92 \mathrm{ppm}$ ) and 95.32 to $297.33 \mathrm{ppm}$ (average $193.79 \mathrm{ppm}$ ), respectively for quartz monzonites, and from 76.84 to $185.9 \mathrm{ppm}$ (average $134.19 \mathrm{ppm}$ ) and 100.82 to $323.5 \mathrm{ppm}$ (average $214.34 \mathrm{ppm}$ ), respectively for nepheline syenites. Y values are relatively higher and range from 467.86 to $1276.19 \mathrm{ppm}$ (average $797.33 \mathrm{ppm}$ ) in nepheline syenite zircons, and from 433 to $1137.57 \mathrm{ppm}$ (average $788.39 \mathrm{ppm}$ ) in quartz monzonite zircons. $\mathrm{Nb}$ and $\mathrm{Ta}$ show low content within the two granitoids samples. Their abundances range from 1.6 to $8.36 \mathrm{ppm}$ (average $2.82 \mathrm{ppm}$ ) and 0.58 to $2.03 \mathrm{ppm}$ (average 0.96 ), respectively for quartz monzonite while in nepheline syenite zircon grains, their contents range from 1.56 to $5.99 \mathrm{ppm}$ (average $3.10 \mathrm{ppm}$ ) and 0.58 to $1.76 \mathrm{ppm}$ (average $1.07 \mathrm{ppm}$ ), respectively. However, $\mathrm{Hf}$ concentrations for all the rocks are close to $8000 \mathrm{ppm}$ (average $=7840 \mathrm{ppm}$ and $8133 \mathrm{ppm}$, respectively for quartz monzonites and nepheline syenites). In general, most of the highest concentrations are found in nepheline syenites and the lowest values in quartz monzonites. This demonstrates the enrichment of $\mathrm{Hf}$ in zircons from nepheline syenite sample relative to quartz-monzonite samples and consequently mirrors their crystallization at a higher degree of magmatic evolution [46].

The chondrite-normalized REE patterns of the zircons grains (Figure 4(a) and Figure 4(b)) show an enrichment of MREE to HREE over LREE from the two samples (quartz monzonites and nepheline syenites). In addition, REE patterns for all zircon types are nearly parallel and show little variation in overall concentrations, reflecting their similar crystallization environment ([48] [49]). Zircons in our samples are characterized by positive $\mathrm{Ce}$ and negative Eu anomalies in chondrite-normalized patterns. The positive $\mathrm{Ce}$ anomaly $\left(\mathrm{Ce} / \mathrm{Ce}^{\star}\right)$ range from 2.27 to 360 and 1.92 to 667 respectively for nepheline syenites and quartz monzonites zircons, which is typical of magmatic zircons ([46] [50]). The Eu anomaly $\left(\mathrm{Eu} / \mathrm{Eu}^{*}\right)$ are weakly negative and range from 0.58 to 0.84 (nepheline 


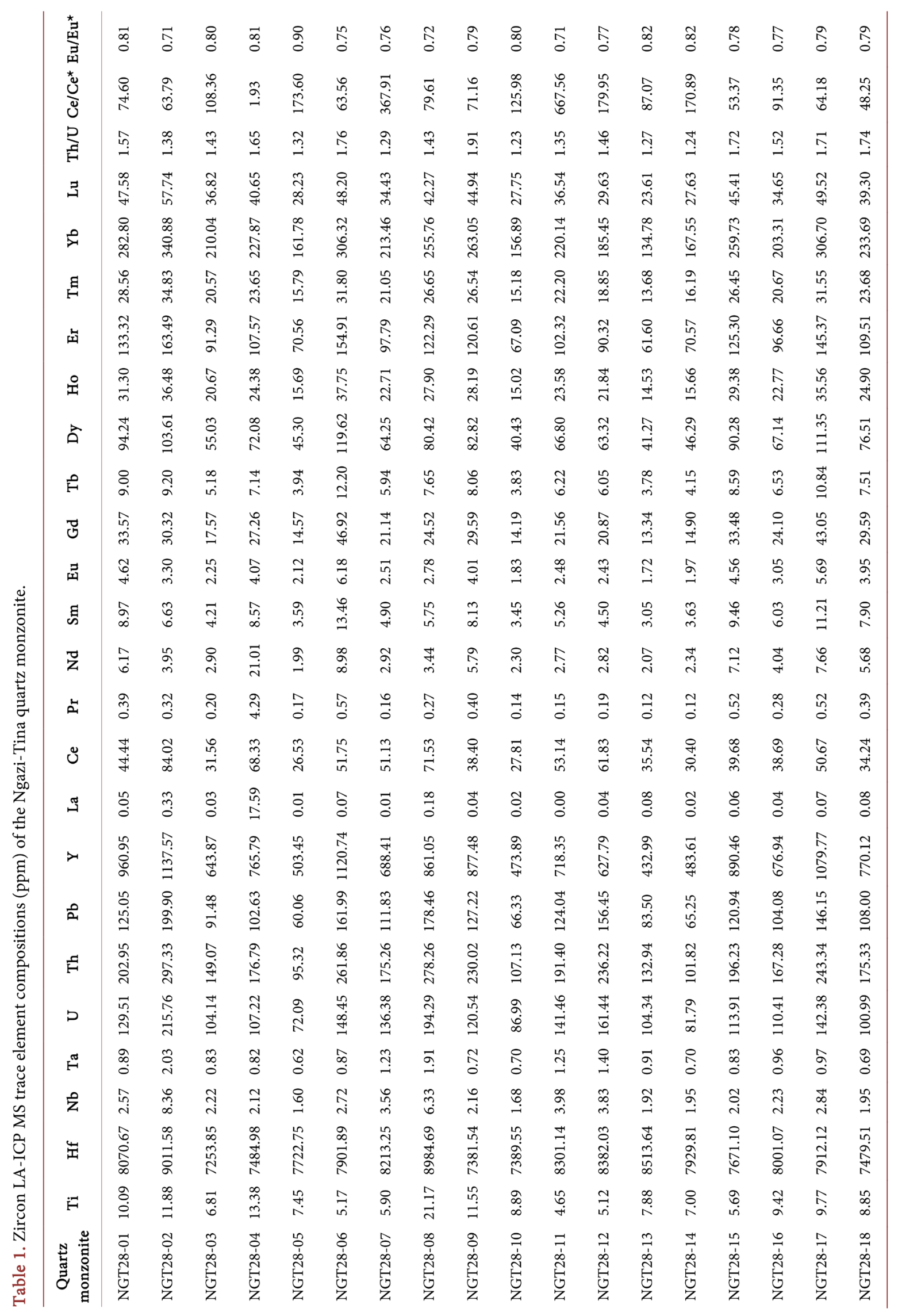




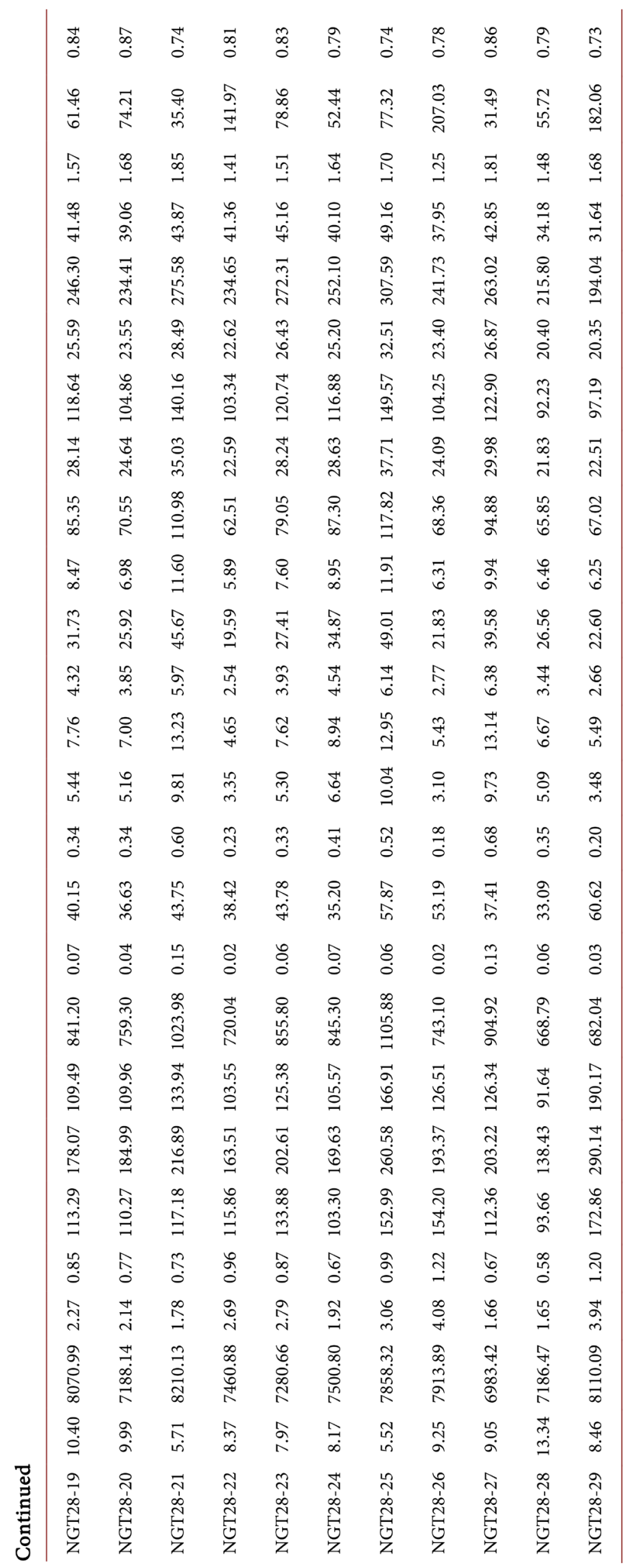




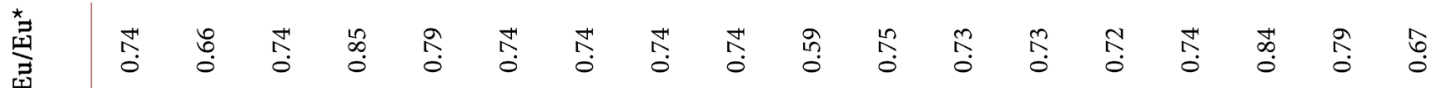

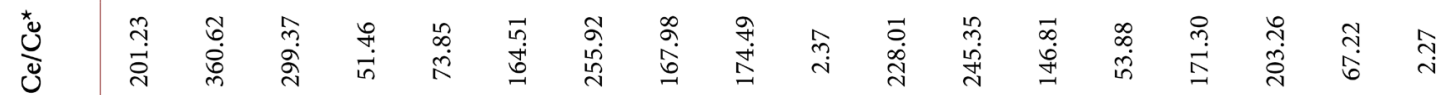
?

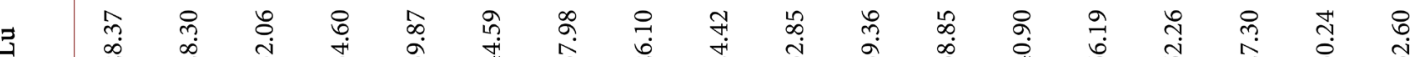

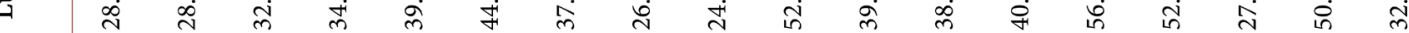

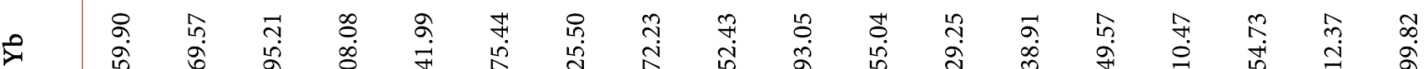

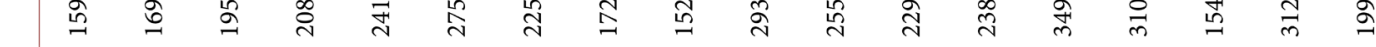

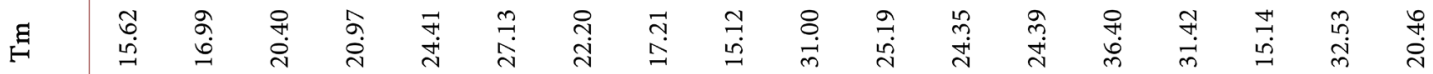

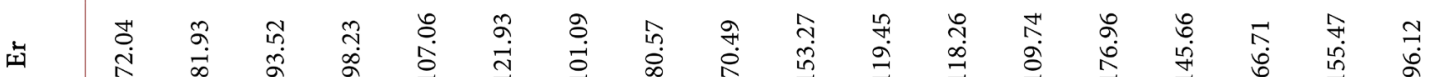

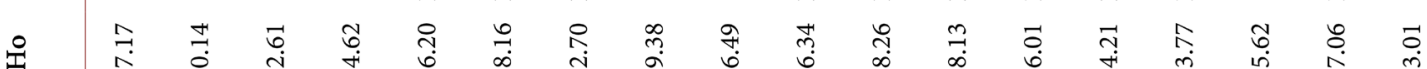

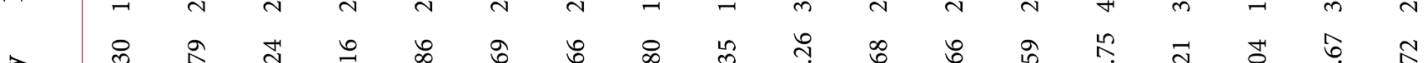

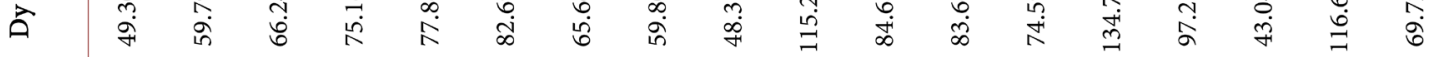

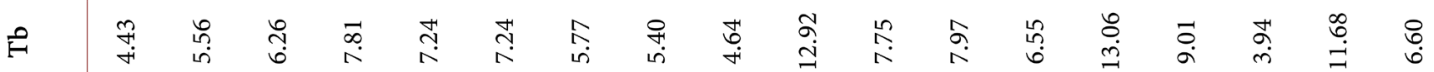

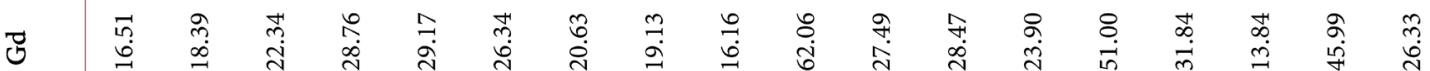

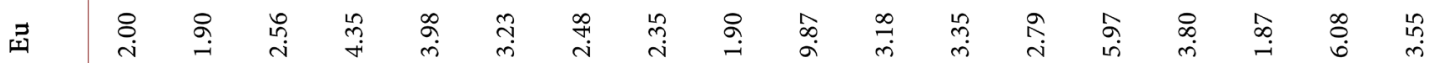

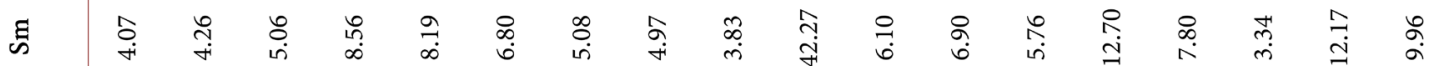

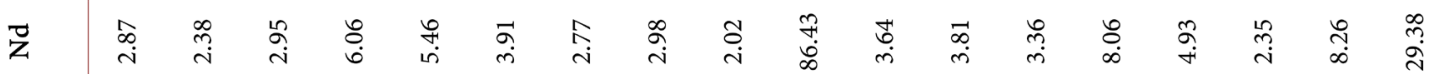

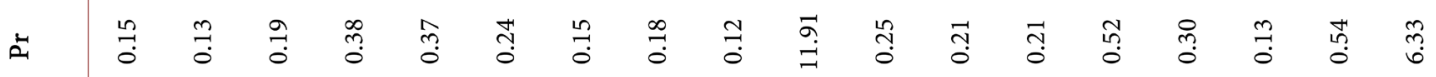

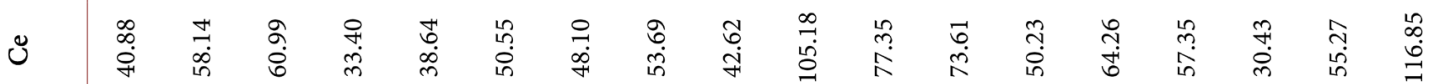

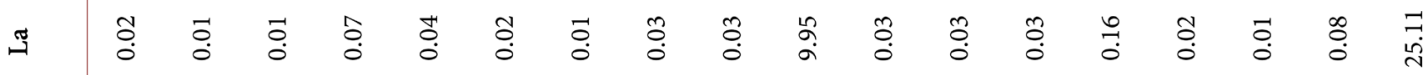

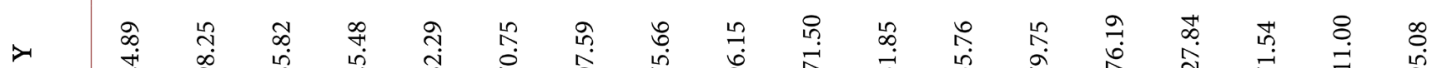

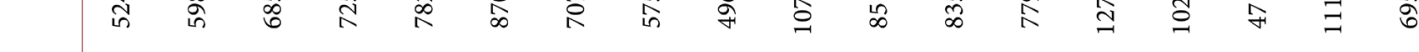

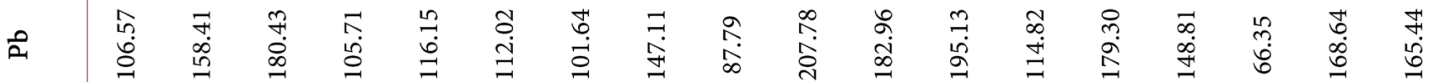
F $\quad \hat{m}$ gे F 仓

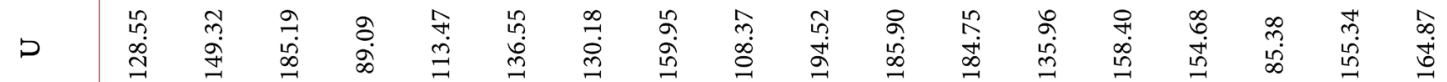

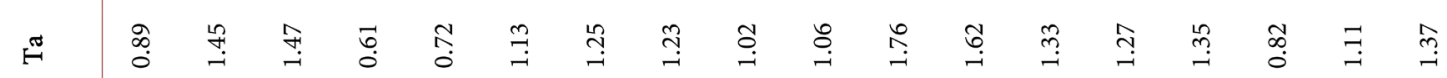

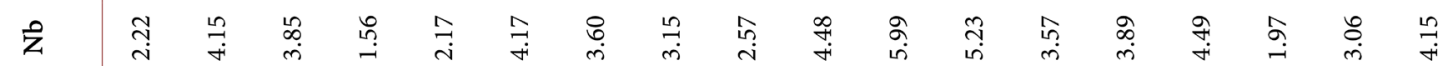
ஸे

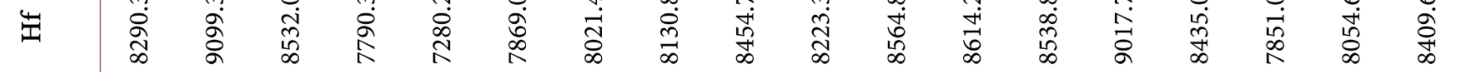

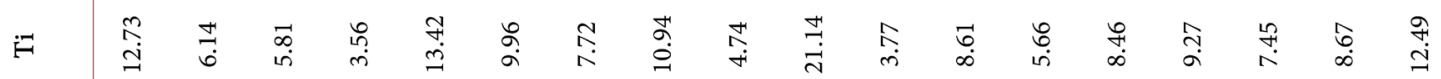

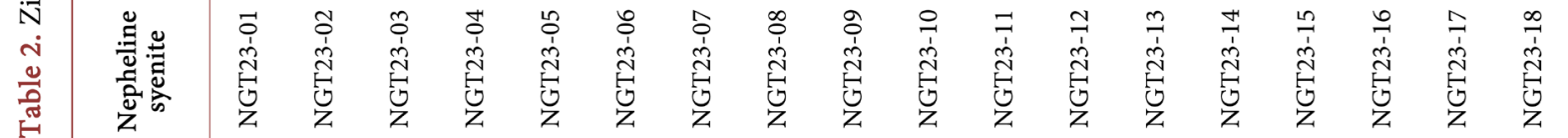




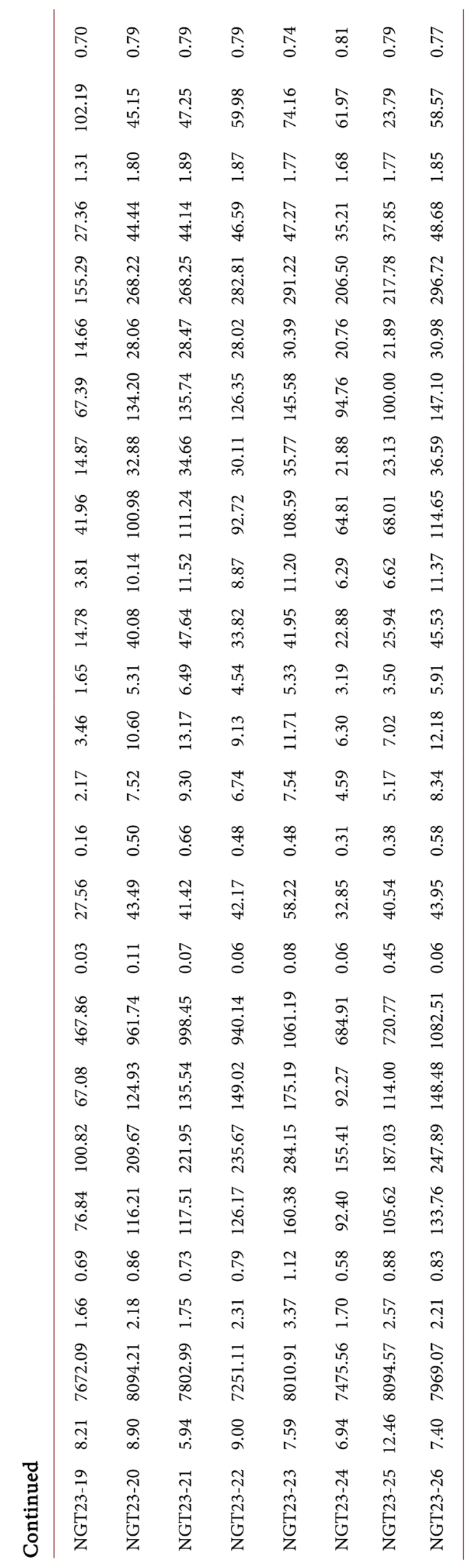




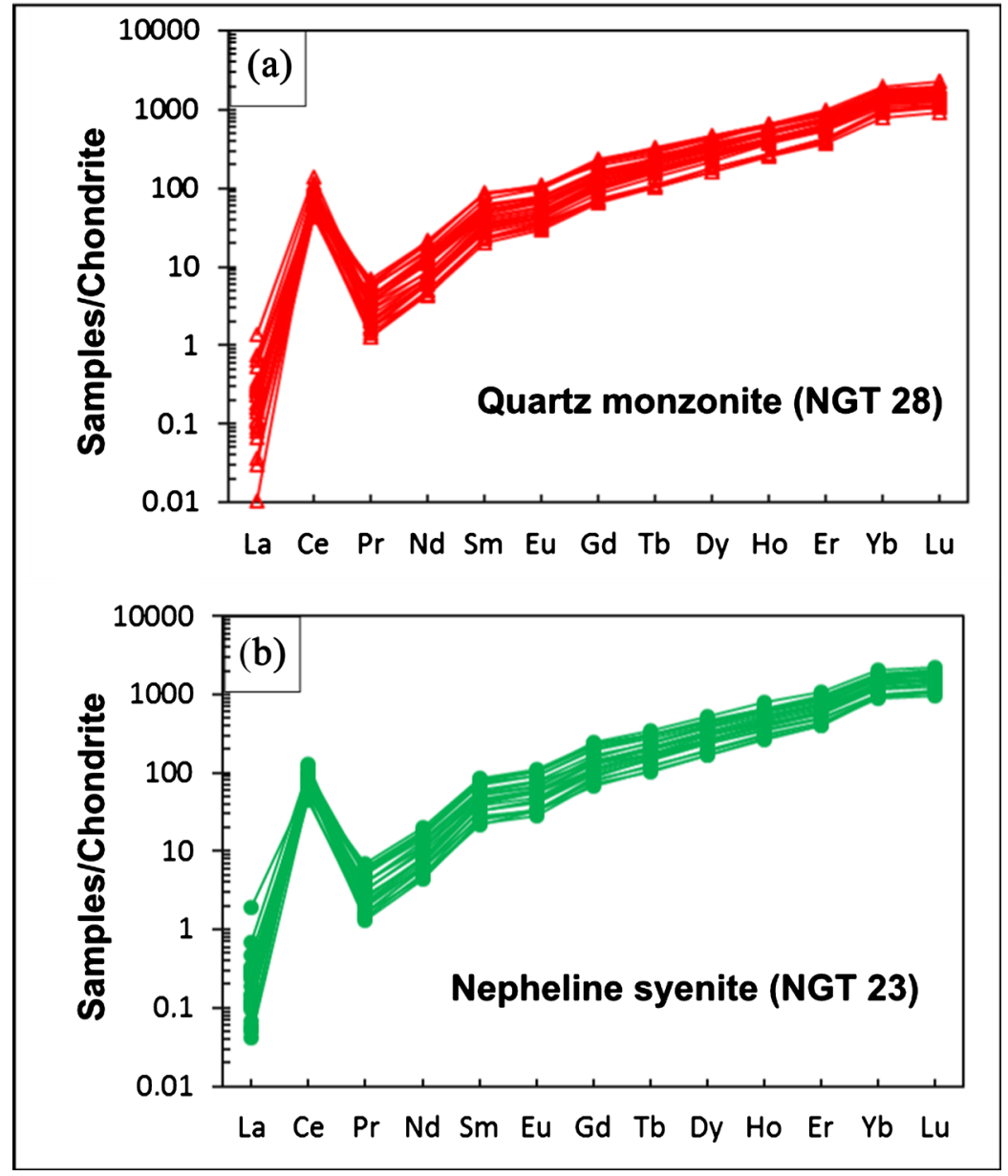

Figure 4. Chondrite-normalized REE patterns for (a) quartz monzonite and (b) nepheline syenite zircons.

syenites) and from 0.71 to 0.89 (quartz monzonites). According to [46], the positive $\mathrm{Eu}$ anomaly is related to oxidation processes or an oxidizing environment, while the negative Eu anomaly is indicative of plagioclase fractionation.

\subsection{Ti-in-Zircon Thermometry}

The Ti-in-zircon thermometer using [51] formula's, indicates a crystallization temperatures ranging from $678^{\circ} \mathrm{C}$ to $811^{\circ} \mathrm{C}$ in quartz monzonites (Table 3). The minimum is observed on the spot NGT28-11 while the maximum is recorded by the spot NGT28-08. The average temperature calculated is ca. $726^{\circ} \mathrm{C}$ (Figure $5(\mathrm{a}))$. In nepheline syenites, the crystallization temperatures vary from $658^{\circ} \mathrm{C}$ (NGT23-04) to $768^{\circ} \mathrm{C}$ (NGT23-05) (Table 3), with an average of ca. $720^{\circ} \mathrm{C}$ (Figure 5(b)), slightly lower than that of quartz monzonite zircons.

\section{Discussion}

Several authors(e.g. [52] [53] [54]) have clearly demonstrated that, zircons generally persist as refractory relics in felsic magma (due to their low solubility in siliceous cast irons) and can potentially retain the chemical and isotopic composition 
Table 3. Temperature calculation using Ti-in-zircon [51].

\begin{tabular}{|c|c|c|c|c|c|}
\hline \multicolumn{3}{|c|}{ Quartz monzonite (NGT 28) } & \multicolumn{3}{|c|}{ Nepheline syenite (NGT23) } \\
\hline Spots & $\mathrm{Ti}(\mathrm{ppm})$ & $\mathrm{T}^{\circ} \mathrm{C}$ & Spots & $\mathrm{Ti}(\mathrm{ppm})$ & $\mathrm{T}^{\circ} \mathrm{C}$ \\
\hline NGT28-01 & 10.08912 & 741.7525 & NGT23-01 & 12.73067 & 762.6465 \\
\hline NGT28-02 & 11.87538 & 756.3084 & NGT23-02 & 6.143902 & 699.8901 \\
\hline NGT28-03 & 6.805972 & 708.2425 & NGT23-03 & 5.805767 & 695.3309 \\
\hline NGT28-04 & 13.38451 & 767.2593 & NGT23-04 & 3.556645 & 657.5803 \\
\hline NGT28-05 & 7.454524 & 715.7924 & NGT23-05 & 13.42217 & 767.5194 \\
\hline NGT28-06 & 5.165868 & 686.0594 & NGT23-06 & 9.95526 & 740.5781 \\
\hline NGT28-07 & 5.904319 & 696.6821 & NGT23-07 & 7.71786 & 718.7027 \\
\hline NGT28-08 & 21.16749 & 811.4666 & NGT23-08 & 10.94303 & 748.9554 \\
\hline NGT28-09 & 11.55414 & 753.8305 & NGT23-09 & 4.738257 & 679.3129 \\
\hline NGT28-10 & 8.887347 & 730.709 & NGT23-11 & 3.772866 & 661.9701 \\
\hline NGT28-11 & 4.651323 & 677.8793 & NGT23-12 & 8.613094 & 728.0166 \\
\hline NGT28-12 & 5.11908 & 685.3444 & NGT23-13 & 5.660993 & 693.3109 \\
\hline NGT28-13 & 7.882294 & 720.4784 & NGT23-14 & 8.462322 & 726.5061 \\
\hline NGT28-14 & 7.001656 & 710.5813 & NGT23-15 & 9.274961 & 734.3993 \\
\hline NGT28-15 & 5.686701 & 693.6727 & NGT23-16 & 7.452777 & 715.7728 \\
\hline NGT28-16 & 9.415033 & 735.7014 & NGT23-17 & 8.667402 & 728.5554 \\
\hline NGT28-17 & 9.766979 & 738.9039 & NGT23-18 & 12.49394 & 760.9282 \\
\hline NGT28-18 & 8.852443 & 730.3702 & NGT23-19 & 8.206788 & 723.8942 \\
\hline NGT28-19 & 10.39598 & 744.397 & NGT23-20 & 8.897553 & 730.8079 \\
\hline NGT28-20 & 9.989299 & 740.878 & NGT23-21 & 5.940538 & 697.174 \\
\hline NGT28-21 & 5.712358 & 694.0325 & NGT23-22 & 9.004617 & 731.8393 \\
\hline NGT28-22 & 8.365758 & 725.5268 & NGT23-23 & 7.594072 & 717.3451 \\
\hline NGT28-23 & 7.970096 & 721.414 & NGT23-24 & 6.941026 & 709.8625 \\
\hline NGT28-24 & 8.169767 & 723.5102 & NGT23-25 & 12.4598 & 760.6782 \\
\hline NGT28-25 & 5.516168 & 691.2465 & NGT23-26 & 7.39872 & 715.1647 \\
\hline NGT28-26 & 9.24678 & 734.1353 & & & \\
\hline NGT28-27 & 9.053663 & 732.3084 & & & \\
\hline NGT28-28 & 13.34217 & 766.9664 & & & \\
\hline NGT28-29 & 8.460677 & 726.4895 & & & \\
\hline
\end{tabular}

of the deep crust. According to [53], zircon can survive various episodes of sedimentary and magmatic recycling, metamorphism and even subduction. In such, trace element concentrations and ratios are widely used to constrain the source of magmatic zircons ([55] [56] [57]). For example, high contents of Y, $\mathrm{Th}, \mathrm{U}, \mathrm{Nb}$ and $\mathrm{Ta}$, as well as enrichment in Ce and depletion in Eu are characteristics of zircons from magmatic melt [58]. In addition, zircons from mantle 


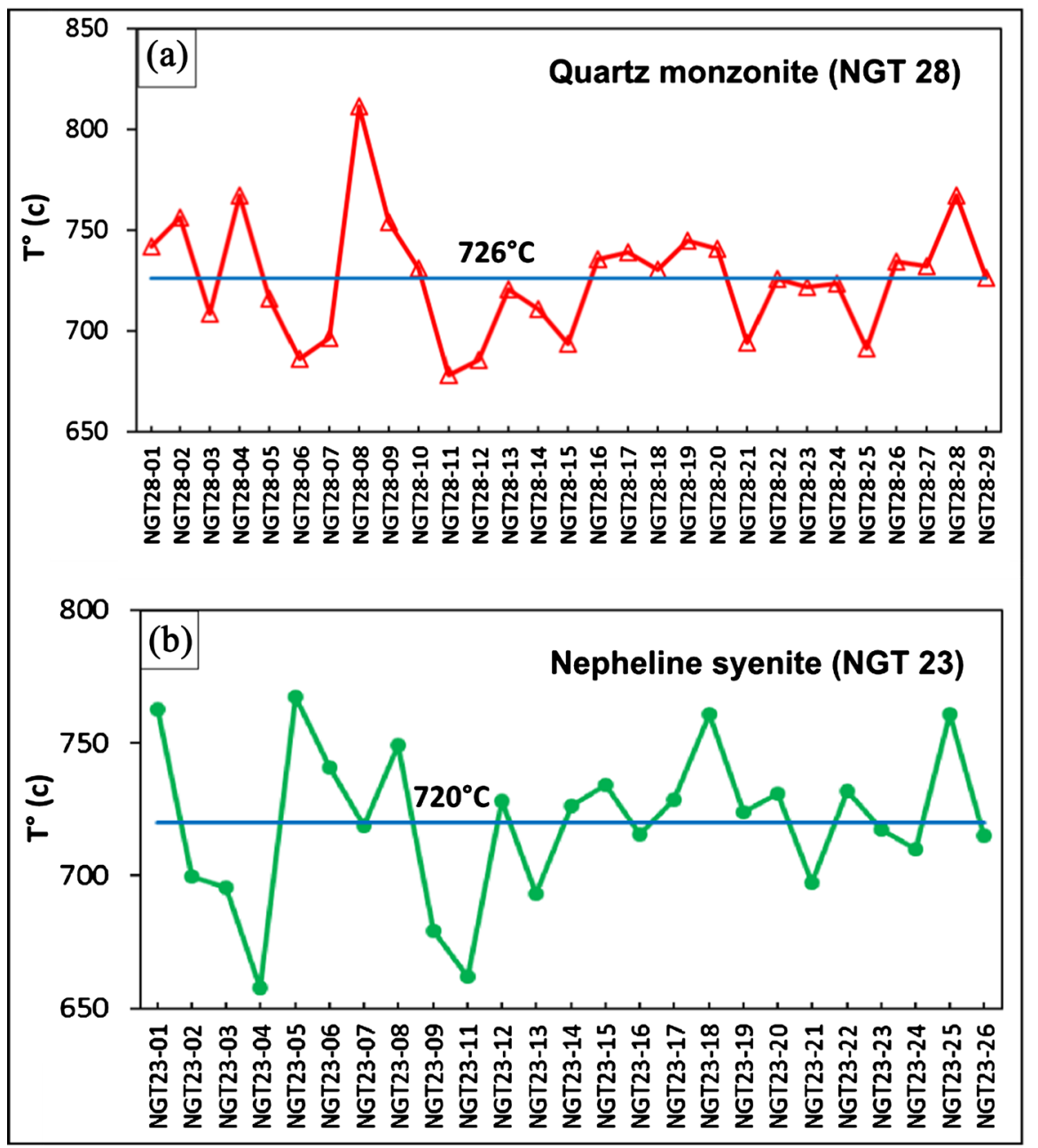

Figure 5. Diagrams showing distribution of temperature obtained from Ti-in-zircon thermometry for each zircon grains (the blue line indicates the average temperature).

magmas show negative correlations of $\mathrm{Hf}$ with Th, $\mathrm{Y}$ and $\mathrm{U}$, in contrast to zircons derived from crust, which show positive correlations [59]. In this study, the Hf vs. Th and $U$ show a positive correlation, suggesting crust derived zircon grains (Figure 6(a) and Figure 6(b)).

In addition, the $\mathrm{U} / \mathrm{Yb}$ ratio can significantly reflect the environments in which the zircons crystallized. Indeed zircons from kimberlites have an average $\mathrm{U} / \mathrm{Yb}$ ratio of 2.1 while the same ratio is relatively low for continental and oceanic crust zircons, 1.07 and 0.8 respectively [60] [61]. To discriminate the source of magma from zircon grains, the $\mathrm{U} / \mathrm{Yb}$ vs. $\mathrm{Hf}$ and $\mathrm{U} / \mathrm{Yb}$ vs. $\mathrm{Y}$ diagrams have been proposed [60]. In these diagrams, all zircon grains of the Ngazi-Tina granitoids are plotted in the field of the continental crust zircons (Figure 6(c) and Figure 6(d)). This interpretation is consistent with the Ti-in-zircon thermometry [51] indicating a crystallization temperature ranging from $678^{\circ}$ to $811^{\circ} \mathrm{C}$ (quartz monzonite) and $658^{\circ} \mathrm{C}$ to $768^{\circ} \mathrm{C}$ (nepheline syenite).

Several authors (e.g. [14] [49] [57] [62] [63]) have used the distribution of trace and REE in zircons as petrogenetic guides. For example, high contents of $\mathrm{U}$ 

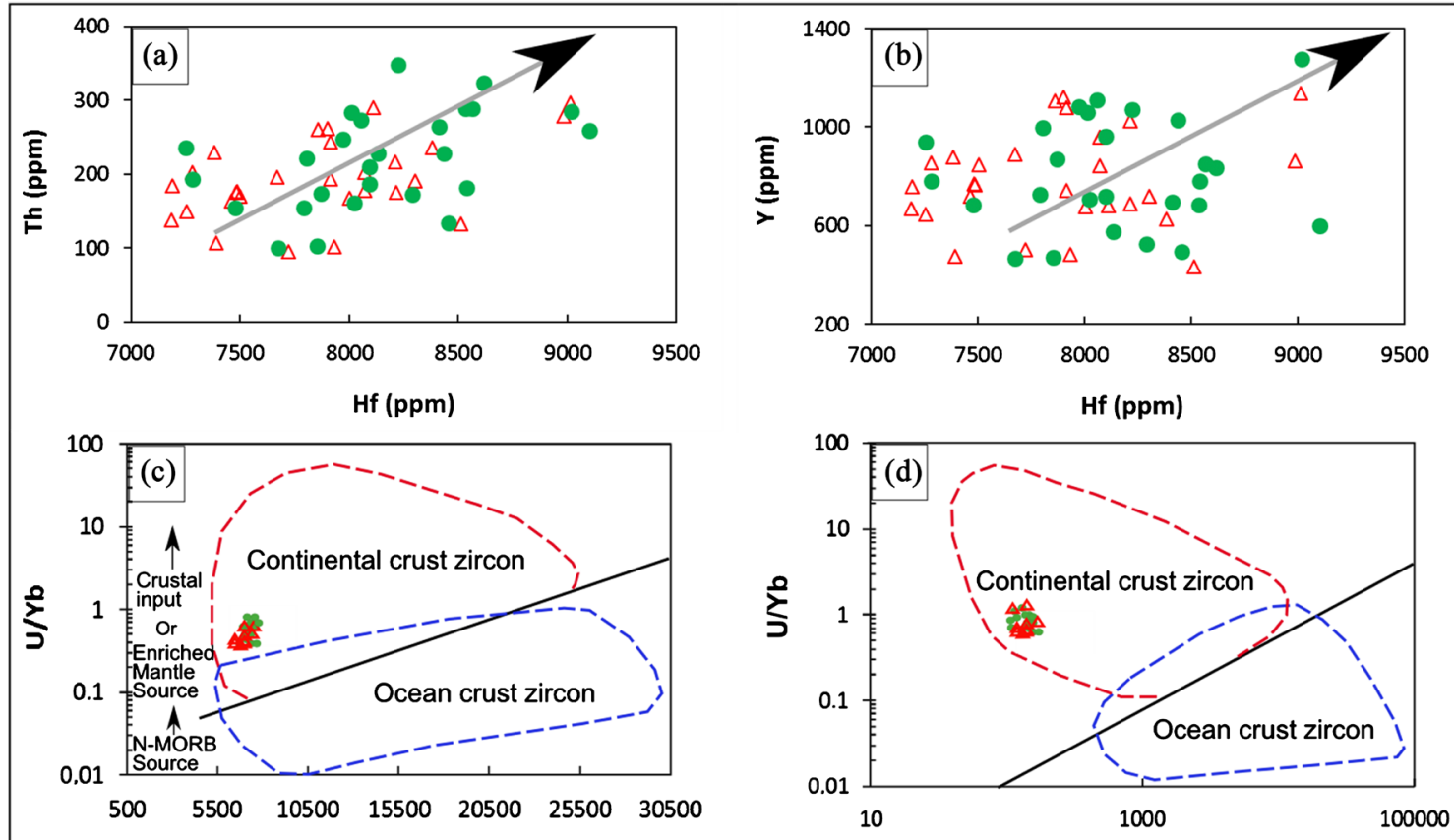

$\mathrm{Hf}$ (ppm)

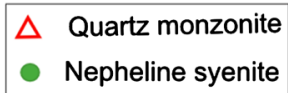

$\mathrm{Yb}(\mathrm{ppm})$

Figure 6. (a) Th vs. Hf; (b) Y vs. Hf bivariate diagrams; (c) U/Yb vs. Hf; (d) U/Yb vs. Yb diagrams between continental and ocean crust zircons [60].
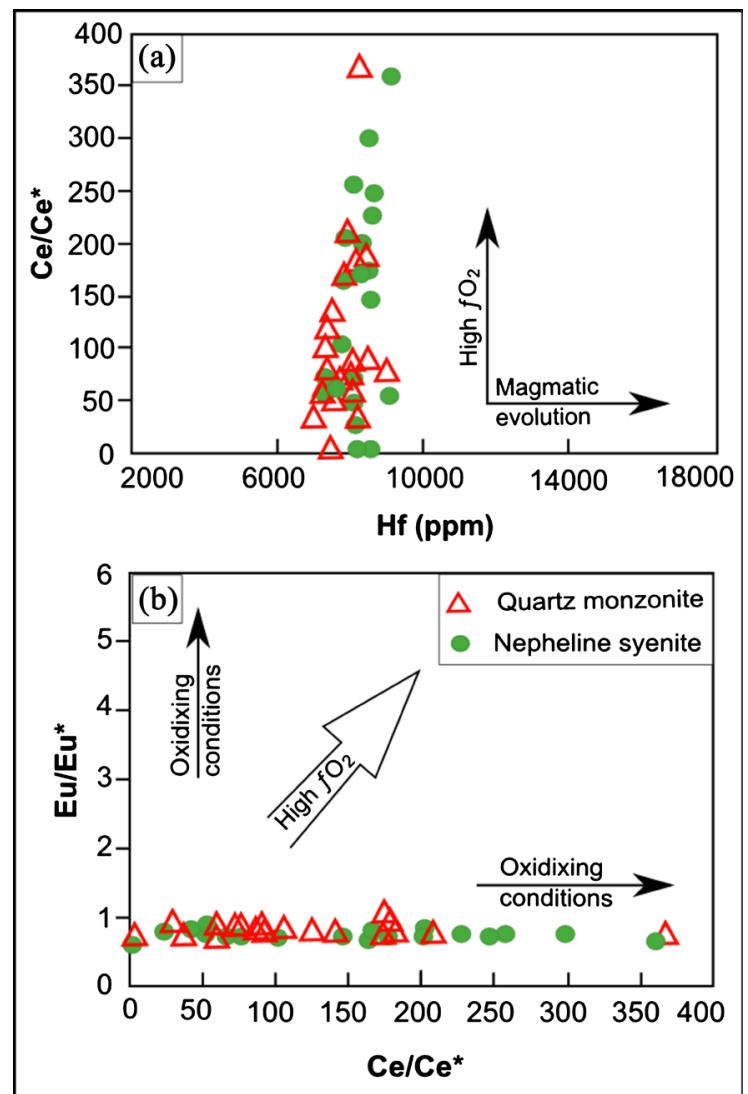

Figure 7. (a) $\mathrm{Ce} / \mathrm{ce}^{\star}$ vs. $\mathrm{Hf}$; (b) $\mathrm{Eu} / \mathrm{Eu}^{\star}$ vs. $\mathrm{Ce} / \mathrm{Ce}^{\star}$ diagrams. 
relative to $\mathrm{Th}$ (low $\mathrm{Th} / \mathrm{U}$ ratios) are features of zircons crystallized from magma at low temperature ([64] [65]). Generally, during magmatic differentiation, $\mathrm{Hf}$ concentrations increase in zircons, hence the low $\mathrm{Zr} / \mathrm{Hf}$ ratio ([61] [66]). To determine the conditions of crystallization of magma, some authors ([49] [54] [57] [61]) have proposed the use of Ce/Ce* vs. Hf diagram. In this plot (Figure 7(a)), the studied zircon grains follow the trend of oxygen fugacity $\left(f \mathrm{O}_{2}\right)$. In addition, the $\mathrm{Eu} / \mathrm{Eu}^{*}$ vs. Ce/Ce* diagram (Figure 7(b)) reveals that these zircons may have crystallized under varying oxidation conditions. The characteristics of zircons described above are also observed in Ekoumedion [13] and Linté [14] granitoids with the AYD. However, Ngazi-Tina zircons are distinguished by the absence of hydrothermal zircons.

The Ngazi-Tina granitoid zircons suggest a compressional-magmatic arc context in the $\mathrm{Nb} / \mathrm{Hf}$ vs. Th/U and Hf/Th vs. Th/Nb (Figure 8(a) and Figure 8(b)) discrimination diagrams [54] [67] where all zircon grains fall within the field of orogenic zircons. Such tectonic environment was recently proposed in the Yoro-Yangben area [68]. This result is consistent with the delamination of the subcrustal lithospheric mantle (SCLM) and asthenospheric uplift ([6] [17] [69]) and

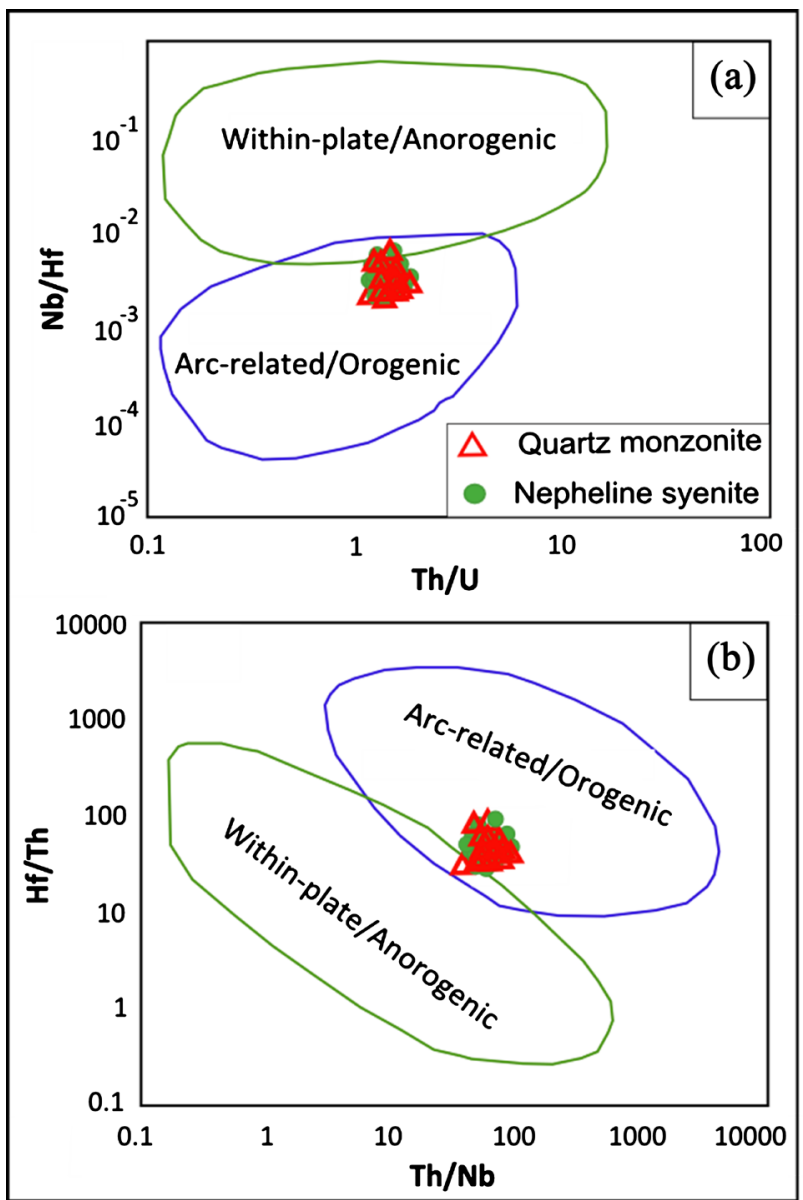

Figure 8. Tectonic discrimination diagrams (a) Hf/Th vs. Th/Nb [54]; (b) Nb/Hf vs. $\mathrm{Th} / \mathrm{U}$ [67]. The blue and green circles indicated the field of orogenic and anorogenic related rocks, respectively. 
resulting in crustal thickening.

\section{Conclusion}

The Ngazi-Tina granitoids zircons display prismatic and pyramidal shapes with light and dark bands, typical of magmatic zircons. The Ti-in-zircon thermometry indicates a crystallization temperature ranging from $678^{\circ} \mathrm{C}$ to $811^{\circ} \mathrm{C}$ (quartz monzonite) and $658^{\circ} \mathrm{C}$ to $768^{\circ} \mathrm{C}$ (nepheline syenite) which is consistent with zircons grew in the continental crust. The chondrite-normalized REE patterns of both zircon samples are similar and display a steeply-rising slope due to serious HREE enrichment and LREE depletion. The depletion in Eu relative to Ce coupled with the different chemical ratios, indicate that these rocks were probably originated from the partial melting of the continental crust. Hf values and $\mathrm{Ce} / \mathrm{Ce}^{\star}, \mathrm{Th} / \mathrm{U}, \mathrm{Zr} / \mathrm{Hf}$ ratios suggest that magma crystallization took place under variable oxidation and oxygen fugacity conditions.

\section{Acknowledgements}

The data presented here form part of the first author's $\mathrm{PhD}$ Thesis at the Department of Earth Sciences of the University of Dschang. This research did not receive any specific grant from funding agencies in the public, commercial, or not-for-profit sectors.

\section{Conflicts of Interest}

The authors declare no conflicts of interest regarding the publication of this paper.

\section{References}

[1] Kröner, A. and Stern, R.J. (2004) Africa/Pan-African Orogeny. In: Selley, R., Cocks, L.R.M. and Plimer, I.R., Eds., Encyclopedia of Geology, Elsevier, Amsterdam, 1-12. https://doi.org/10.1016/B0-12-369396-9/00431-7

[2] Rino, S., Kon, Y., Sato, W., Maruyama, S., Santosh, M. and Zhao, D.P. (2008) The Grenvillian and Pan-African Orogens: World's Largest Orogenies through Geologic Time, and Their Implications on the Origin of Superplume. Gondwana Research, 14, 51-72. https://doi.org/10.1016/j.gr.2008.01.001

[3] Agbossoumondé, Y., Ménot, R.P., Paquette, J.L., Guillot, S., Yéssoufou, S. and Perrache, C. (2007) Petrological and Geochronological Constraints on the Origin of the Palimé-Amlamé Granitoids (South Togo, West Africa): A Segment of the West African Craton Paleoproterozoic Margin Reactivated during the Pan-African Collision. Gondwana Research, 12, 476-488. https://doi.org/10.1016/j.gr.2007.01.004

[4] Tanko Njiosseu, E.L., Nzenti, J.P., Njanko, T., Kapajika, B. and Nedelec, A. (2005) New U-Pb Zircon Ages from Tonga (Cameroon): Coexisting Eburnean Transamazonian $(2.1 \mathrm{Ga})$ and Pan-African (0.6 Ga) Imprints. Compte Rendu Géosciences, 337, 551-562. https://doi.org/10.1016/j.crte.2005.02.005

[5] Tchameni, R., Pouclet, A., Penaye, J., Ganwa, A.A. and Toteu, S.F. (2006) Petrography and Geochemistry of the Ngaoundéré Pan-African Granitoids in Central North 
Cameroon: Implications for Their Sources and Geological Setting. Journal of African Earth Sciences, 44, 511-529.

https://doi.org/10.1016/j.jafrearsci.2005.11.017

[6] Kwekam, M., Légeois, J.P., Njonfang, E., Affaton, P., Hartmann, G. and Tchoua, F. (2010) Nature, Origin, and Significance of the Fomopéa Pan-African High-k Calc-Alkaline Plutonic Complex in the Central African Fold Belt (Cameroon). Journal of African Earth Sciences, 57, 79-95.

https://doi.org/10.1016/j.jafrearsci.2009.07.012

[7] Isseini, M., André Mayer, A.S., Vanderhaeghe, O., Barbey, P. and Deloule, E. (2012) A-Type Granites from the Pan-African Orogenic Belt in South-Western Chad Constrained Using Geochemistry, Sr-Nd Isotopes and U-Pb Geochronology. Lithos, 153, 39-52. https://doi.org/10.1016/j.lithos.2012.07.014

[8] Dawaï, D., Bouchez, J.L., Paquette, J.L. and Tchameni, R. (2013) The Pan-African Quartz-Syenite of Guider (North-Cameroon): Magnetic Fabric and U-Pb Dating of a Late-Orogenic Emplacement. Precambrian Research, 236, 132-144.

https://doi.org/10.1016/j.precamres.2013.07.008

[9] Li, X.H., Chen, Y., Tchouankoue, J.P., Liu, C., Li, J., Ling, X., Tang, G. and Liu, Y. (2017) Improving Geochronological Framework of the Pan-African Orogeny in Cameroon: New SIMS Zircon and Monazite U-Pb Age Constraints. Precambrian Research, 294, 307-321. https://doi.org/10.1016/j.precamres.2017.04.006

[10] Shellnutt, J.G., Pham, N.H.T., Denyszyn, S.W., Yeh, M.-W. and Lee, T.-Y. (2017) Timing of Collisional and Post-Collisional Pan-African Orogeny Silicic Magmatism in South-Central Chad. Precambrian Research, 301, 113-123. https://doi.org/10.1016/j.precamres.2017.08.021

[11] Amorim, J.V.A.D., Guimarães, I.D.P., Farias, D.J.S., Lima, J.V.D., Santos, L., Ribeiro, V.B. and Brainer, C. (2019) Late-Neoproterozoic Ferroan Granitoids of the Transversal Subprovince, Borborema Province, NE Brazil: Petrogenesis and Geodynamic Implications. International Geology Review, 61, 1745-1767. https://doi.org/10.1080/00206814.2018.1544936

[12] Baidada, B., Ikenne, M., Barbey, P., Soulaimani, A., Cousens, B., Haissen, F., Ilmen, S. and Alansari, A. (2019) SHRIMP U-Pb Zircon Geochronology of the Granitoids of the Imiter Inlier: Constraints on the Pan-African Events in the Saghro Massif, Anti-Atlas (Morocco). Journal of African Earth Sciences, 150, 799-810.

https://doi.org/10.1016/j.jafrearsci.2018.10.008

[13] Embui, V.F., Suh, C.E., Cottle, J.M., Etame, J., Mendes, J., Agyingi, C.M., Vishiti, A., Shemang, E.M. and Lehmann, B. (2019). Zircon Chemistry and New Laser Ablation $\mathrm{U}-\mathrm{Pb}$ Ages for Uraniferous Granitoids in SW Cameroon. Acta Geochimica, 39, 43-66. https://doi.org/10.1007/s11631-019-00337-x

[14] Ayonta Kenne, P., Tanko Njiosseu, E.L., Ganno, S., Ngnotue, T., Fossi, D.H., Hamdja Ngoniri, A., Nga Essomba, P. and Nzenti, J.P. (2021) Zircon Element Trace Geochemistry and Ti-in-Zircon Thermometry of the Linté Pan-African Post-Collisional Granitoids, Central Cameroon: Constraints on the Genesis of Host Magma and Tectonic Implications. Geological Journal (accepted).

[15] Penaye, J., Toteu, S.F., Michard, A., Van Schmus, W.R. and Nzenti, J.P. (1993) U-Pb and Sm-Nd Preliminary Geochronologic Data on the Yaoundé Serie, Cameroon: Reinterpretation of Granulitic Rocks as the Suture of the Collision in the Centrafrican Belt. Comptes Rendus de 1 Académie des Sciences, 317, 789-794.

[16] Toteu, S.F., Van Schumus, W.R., Penaye, J. and Michard, A. (2001) New U-Pb and Sm-Nd Data from North-Central Cameroon and Its Bearing on the Pre-Pan African 
History of Central Africa. Precambrian Research, 108, 45-73. https://doi.org/10.1016/S0301-9268(00)00149-2

[17] Toteu, S.F., Penaye, J. and Poudjom, D.Y. (2004) Geodynamic Evolution of the Pan-African Belt of Central Africa with Special Reference to Cameroon. Canadian Journal of Earth Sciences, 41, 73-85. https://doi.org/10.1139/e03-079

[18] Trompette, R. (1994) Geology of Western Gondwana (2000-500 Ma). Pan-AfricanBrasiliano Aggregation of South America and Africa. A. A. Balkema Edition, Rotterdam, $350 \mathrm{p}$.

[19] Trompette, R. (1997) Neoprotozoïc (600 Ma) Aggregation of Western Gondwana: A Tentative Scenario. Precambrian Research, 82, 101-112. https://doi.org/10.1016/S0301-9268(96)00045-9

[20] Nzenti, J.P., Barbey, P., Bertrand, J.M. and Macaudiere, J. (1994) La chaine panafricaine au Cameroun: Cherchons structures et modèles. In S.G.F. édit. 15e, réunion des Sciences de la terre, Nancy, $99 \mathrm{p}$.

[21] Ngnotué, T., Ganno, S., Nzenti, J.P., Schulz, B., Tchaptchet Tchato, D. and Suh Cheo, E. (2012) Geochemistry and Geochronology of Peraluminous High-K Granitic Leucosomes of Yaounde Series (Cameroon): Evidence for a Unique Pan-African Magmatism and Melting Event in North-Equatorial Fold Belt. International Journal of Geosciences, 3, 525-548.

https://doi.org/10.4236/ijg.2012.33055

[22] Djouka-Fonkwé, M.L., Schulz, B., Schüssler, U., Tchouankoué, J.P. and Nzolang, C. (2008) Geochemistry of the Bafoussam Pan-African I- and S-Type Granitoids in Western Cameroon. Journal of African Earth Sciences, 50, 148-167.

https://doi.org/10.1016/j.jafrearsci.2007.09.015

[23] Van Schmus, W.R., Oliveira, E.P., Da Silva Filho, A.F., Toteu, S.F., Penaye, J. and Guimaraes, I.P. (2008) Proterozoic Links between the Borborema Province, NE Brazil, and the Central African Fold Belt. Geological Society of London Special Publication, 294, 69-99. https://doi.org/10.1144/SP294.5

[24] Nzenti, J.P., Njanko, T., Njiosseu, E.L.T. and Tchoua, F.M. (1998) Les domaines granulitiques de la chaîne panafricaine Nord-Equatoriale au Cameroun. In: Vicat and Bilong, Eds., Géologie et environnement au Cameroun, Collection Geocam I/1998, Université de Yaoundé I, Yaoundé, 255-264.

[25] Nzenti, J.P., Njiosseu Tanko, E.L. and Nzina, N.A. (2007) The Metamorphic Evolution of the Paleoproterozoic High Grade Banyo Gneisses (Adamawa, Cameroon, Central Africa). Journal of Cameroun Academy of Sciences, 7, 95-109.

[26] Ganwa, A.A., Frisch, W., Siebel, W., Ekodeck, G.E., Cosmas, S.K. and Ngako, V. (2008) Archean Inheritances in the Pyroxene-Amphibole-Bearing Gneiss of the Méiganga Area (Central North Cameroon): Geochemical and ${ }^{207} \mathrm{~Pb} /{ }^{206} \mathrm{~Pb}$ Age Imprints. Comptes Rendus Géosciences, 340, 211-222.

https://doi.org/10.1016/j.crte.2007.12.009

[27] Hamdja Ngoniri, A., Ngnotue, T., Tanko Njiosseu, Ayonta Kenne, P., Ganno, S. and Nzenti, J.P. (2020) Geochemistry of the Neoproterozoic Mbondo-Ngazi-Tina Metasediments, Adamawa Area, Central Cameroon: Source Provenance and Tectonic Setting. Journal Geosciences and Geomatics, 8, 94-109. https://doi.org/10.12691/jgg-8-2-5

[28] Penaye, J., Toteu, S.F., Michard, A., Bertrand, J.M. and Dautel, D. (1989) Reliques granulitiques d'âge protérozoïque inférieur dans la zone mobile Panafricaine d'Afrique Centrale au Cameroun: Géochronologie U-Pb sur zircon. Compte Rendu de 1 Académie des Sciences, 309, 315-318. 
[29] Ganwa, A.A., Klötzli, U.S. and Hauzenberger, C. (2016) Evidence for Archean Inheritance in the Pre-Panafrican Crust of Central Cameroon: Insight from Zircon Internal Structure and LA-MC-ICP-MS U-Pb Ages. Journal of African Earth Sciences, 120, 12-22. https://doi.org/10.1016/j.jafrearsci.2016.04.013

[30] Tchakounte, N.J., Eglinger, A., Toteu, S.F., Zeh, A., Nkoumbou, C., Mvondo Ondoa, J., Penaye, P., De Wit, M. and Barbey, P. (2017) The Adamawa-Yadé Domain, a Piece of Archaean Crust in the Neoproterozoic Central African Orogenic Belt (Bafia area, Cameroon). Precambrian Research, 299, 210-229.

https://doi.org/10.1016/j.precamres.2017.07.001

[31] Tagne-Kamga, G. (2003) Petrogenesis of Neoproterozoic Ngondo Plutonic Complex (Cameroon West Central Africa): A Case of Late Collisional Ferro-Potassic Magmatism. Journal of African Earth Sciences, 36, 149-171.

https://doi.org/10.1016/S0899-5362(03)00043-5

[32] Njanko, T., Nédélec, A. and Affaton, P. (2006) Synkematic High-Kcalc-Alkaline Plutons Associated with the Pan-African Central Cameroon Shear Zone (W-Tibati Area): Petrology and Geodynamic Significance. Journal of African Earth Sciences, 44, 494-501. https://doi.org/10.1016/j.jafrearsci.2005.11.016

[33] Nzenti, J.P., Kapajika, B., Wörner, G. and Lubala, R.T. (2006) Synkinematic Emplacement of Granitoids in a Pan-African Shear Zone in Central Cameroon. Journal of African Earth Sciences, 45, 74-86. https://doi.org/10.1016/j.jafrearsci.2006.01.005

[34] Asaah, A.V., Zoheir, B., Lehmann, B., Frei, D., Burgess, R. and Suh, C.E. (2014) Geochemistry and Geochronology of the $\sim 620$ Ma Gold-Associated Batouri Granitoids, Cameroon. International Geology Review, 57, 1485-1509. https://doi.org/10.1080/00206814.2014.951003

[35] Njiékak, G., Wolfgang, D., Tchouakoué, J. and Zulauf, G. (2008) U-Pb Zircon and Microfabric of (Meta) Granitoids of Western Cameroon: Constraints on the Timing of Pluton Emplacement and Deformation in Africa. Lithos, 102, 460-477. https://doi.org/10.1016/j.lithos.2007.07.020

[36] Ganwa, A.A., Frisch, W., Siebel, W., Ekodeck, G.E. and Shang, C.K. (2011) Geochemistry of Magmatic Rocks and Time Constraints on Deformational Phases and Shear Zone Slip in the Méiganga Area, Central Cameroun. International Geology Review, 53, 759-784. https://doi.org/10.1080/00206810903211161

[37] Kwékam, M., Affaton, P., Bruguier, O., Liégeois, J.P., Hartmann, G. and Njonfang, E. (2013) The Pan-African Kekem Gabbro-Norite (West-Cameroon), U-Pb Zircon Age, Geochemistry and Sr-Nd Isotopes: Geodynamical Implication for the Evolution of the Central African Fold Belt. Journal of African Earth Sciences, 84, 70-88. https://doi.org/10.1016/j.jafrearsci.2013.03.010

[38] Kwékam, M., Talla, V., Fozing, E.M., Tcheumenak Kouémo, J., Dunkl, I. and Njonfang, E. (2020) The Pan-African High-K I-Type Granites from Batié Complex, West Cameroon: Age, Origin, and Tectonic Implications. Frontiers in Earth Science, 8, 363. https://doi.org/10.3389/feart.2020.00363

[39] Hamdja Ngoniri, A., Soh Tamehe, L., Ganno, S., Ngnotue, T., Chen, Z., Li, H., Ayonta Kenne, P. and Nzenti, J.P. (2021) Geochronology and Petrogenesis of the Pan-African Granitoids from Mbondo-Ngazi-Tina in the Adamawa-Yadé Domain, Central Cameroon. International Journal of Earth Science (submitted).

[40] Bao, Z., Sun, W., Li, C. and Zhao, Z. (2014) U-Pb Dating of Hydrothermal Zircon from the Dongping Gold Deposit in North China: Constraints on the Mineralization Processes. Ore Geology Reviews, 61, 107-119. 
https://doi.org/10.1016/j.oregeorev.2014.02.006

[41] He, J., Xu, B. and Li, D. (2019) Newly Discovered Early Neoproterozoic (ca. 900 Ma) Andesitic Rocks in the Northwestern Tarim Craton: Implications for the Reconstruction of the Rodinia Supercontinent. Precambrian Research, 325, 55-68. https://doi.org/10.1016/j.precamres.2019.02.018

[42] Tchouankoue, J.P., Xian-Hua, L., Ngo Belnoun, R.N., Mouafo, L. and Ferreira, V.P. (2016) Timing and Tectonic Implications of the Pan-African Bangangte Syenomonzonite, West Cameroon: Constraints from In-Situ Zircon U-Pb Age and Hf-O Isotopes. Journal of African Earth Sciences, 124, 94-103. https://doi.org/10.1016/j.jafrearsci.2016.09.009

[43] Wiedenbeck, M., Alle, P., Corfu, F., Griffin, W.L., Meier, M., Oberli, F., Vonquadt, A., Roddick, J.C. and Speigel, W. (1995) Three Natural Zircon Standards for $\mathrm{U}-\mathrm{Th}-\mathrm{Pb}$, Lue Hf, Trace-Element and REE Analyses. Geostandards Newsletter, 19, 1-23. https://doi.org/10.1111/j.1751-908X.1995.tb00147.x

[44] Wiedenbeck, M., Hanchar, J.M., Peck, W.H., Sylvester, P., Valley, J., Whitehouse, M., Kronz, A., Morishita, Y., Nasdala, L., Fiebig, J., Franchi, I., Girad, J.P., Greenwood, R.C., Hinton, R., Kita, N., Mason, P.R.D., Norman, M., Ogasawara, M., Piccoli, R., Rhede, D., Satoh, H., Schulz-Dobrik, B., Skar, O., Spiccuza, M.J., Terada, K., Tindle, A., Togashi, S., Vennemann, T., Xie, Q. and Zheng, Y.F. (2004) Further Characterization of the 91500 Zircon Cristal. Geostandards and Geoanalytical Research, 28, 9-39. https://doi.org/10.1111/j.1751-908X.2004.tb01041.x

[45] Hoskin, P.W.O. and Black, L.P. (2000) Metamorphic Zircon Formation by Solid-State Recrystallization of Protolith Igneous Zircon. Journal of Metamorphic Geology, 18, 423-439. https://doi.org/10.1046/j.1525-1314.2000.00266.x

[46] Hoskin, P.W.O. and Schaltegger, U. (2003) The Composition of Zircon and Igneous and Metamorphic Petrogenesis. Reviews in Mineralogy and Geochemistry, 53, 27-62. https://doi.org/10.2113/0530027

[47] Sun, S.S. and McDonough, W.F. (1989) Chemical and Isotopic Systematics of Oceanic Basalts: Implications for Mantle Composition and Processes. In: Saunders, A.D. and Norry, M.J., Eds., Magmatism in Oceanic Basins, Geological Society of London, Special Publication, London, 313-345.

https://doi.org/10.1144/GSL.SP.1989.042.01.19

[48] Cao, Y., Li, S.R., Zhang, H.F., Liu, X.B., Li, Z.Z., Ao, C. and Yao, M.J. (2011) Significance of Zircon Trace Element Geochemistry, the Shihu Gold Deposit, Western Hebei Province, North China. Journal of Rare Earths, 29, 277-286.

https://doi.org/10.1016/S1002-0721(10)60445-0

[49] Deng, C.Z., Sun, G.Y., Sun, D.Y., Han, J., Yang, D. and Tang, Z. (2019) Morphology, Trace Elements, and Geochronology of Zircons from Monzogranite in the Northeast Xing'an Block, Northeastern China: Constraints on the Genesis of the Host Magma. Mineralogy and Petrology, 113, 651-666. https://doi.org/10.1007/s00710-019-00669-9

[50] Rubatto, D. (2017) Zircon: The Metamorphic Mineral. Reviews in Mineralogy and Geochemistry, 83, 261-296. https://doi.org/10.2138/rmg.2017.83.9

[51] Watson, E.B., Wark, D.A. and Thomas, J.B. (2006) Crystallization Thermometers for Zircon and Rutile. Contribution to Mineralogy and Petrology, 151, 413-433. https://doi.org/10.1007/s00410-006-0068-5

[52] Watson, E.B. and Harrison, T.M. (1983) Zircon Saturation Revisited: Temperature and Composition Effects in a Variety of Crustal Magma Types. Earth and Planetary Science Letters, 64, 295-304. https://doi.org/10.1016/0012-821X(83)90211-X 
[53] Gao, S., Rudnick, R.L., Yuan, H.L., Liu, X.M., Liu, Y.S., Xu, W.L., Ling, W.L., Ayers, J., Wang, X.C. and Wang, Q.H. (2004) Recycling Lower Continental Crust in the North China Craton. Nature, 432, 892-897. https://doi.org/10.1038/nature03162

[54] Hawkesworth, C.J. and Kemp, A.I.S. (2006) Using Hafnium and Oxygen Isotopes in Zircons to Unravel the Record of Crustal Evolution. Chemical Geology, 226, 144-162. https://doi.org/10.1016/j.chemgeo.2005.09.018

[55] Li, H., Watanabe, K. and Yonezu, K. (2014) Zircon Morphology, Geochronology and Trace Element Geochemistry of the Granites from the Huangshaping Polymetallic Deposit, South China: Implications for the Magmatic Evolution and Mineralization Processes. Ore Geology Reviews, 60, 14-35.

https://doi.org/10.1016/j.oregeorev.2013.12.009

[56] Wu, R.X., Zheng, Y.F., Wu, Y.B., Zhao, Z.F., Zhang, S.B., Liu, X. and Wu, F.Y. (2006) Reworking of Juvenile Crust: Element and Isotope Evidence from Neoproterozoic Granodiorite in South China. Precambrian Research, 146, 179-212. https://doi.org/10.1016/j.precamres.2006.01.012

[57] Sakyi, A.P., Su, B., Kwayisi, D., Chen, C., Bai, Y. and Alemayehu, M. (2019) Zircon Trace Element Constraints on the Evolution of the Paleoproterozoic Birimian Granitoids of the West African Craton (Ghana). Journal of Earth Science, 29, 43-56. https://doi.org/10.1007/s12583-017-0799-4

[58] Lei, W.Y., Shi, G.H. and Liu, Y.X. (2013) Research Progress on Trace Element Characteristics of Zircons of Different Origins. Frontiers of Earth Sciences, 20, 1-12.

[59] Wang, X. and Pupin, J.P. (1992) Distribution Characteristics of Trace Elements in Zircons from Granitic Rocks. Scientia Geologica Sinica, 2, 131-140.

[60] Grimes, C.B., John, B.E., Kelemen, P.B., Mazdab, F., Wooden, J.L., Cheadle, M.J., Hanghøj, K. and Schwartz, J.J. (2007) The Trace Element Chemistry of Zircons from Oceanic Crust: A Method for Distinguishing Detrital Zircon Provenance. Geology, 35, 643-646. https://doi.org/10.1130/G23603A.1

[61] El-Bialy, M.Z. and Ali, K.A. (2013) Zircon Trace Element Geochemical Constraints on the Evolution of the Ediacaran (600-614 Ma) Post-Collisional Dokhan Volcanics and Younger Granites of SE Sinai, NE Arabian-Nubian Shield. Chemical Geology, 360, 54-73. https://doi.org/10.1016/j.chemgeo.2013.10.009

[62] Belousova, E.A., Griffin, W.L., O’Reilly, S.Y. and Fisher, N.I. (2002) Igneous Zircon: Trace Element Composition as an Indicator of Source Rock Type. Contributions to Mineralogy and Petrology, 143, 602-622. https://doi.org/10.1007/s00410-002-0364-7

[63] Belousova, E.A., Griffin, W.L. and O’Reilly, S.Y. (2006) Zircon Crystal Morphology, Trace Element Signatures and Hf Isotope Composition as a Tool for Petrogenetic Modelling: Examples from Eastern Australian Granitoids. Journal of Petrology, 47, 329-353. https://doi.org/10.1093/petrology/egi077

[64] Gagnevin, D., Daly, J.S. and Kronz, A. (2010) Zircon Texture and Chemical Composition as a Guide to Magmatic Processes and Mixing in a Granitic Environment and Coeval Volcanic System. Contributions to Mineralogy and Petrology, 159, 579-596. https://doi.org/10.1007/s00410-009-0443-0

[65] Wang, X., Griffin, W.L. and Chen, J. (2011) U and Th Contents and Th/U Ratios of Zircon in Felsic and Mafic Magmatic Rocks: Improved Zircon-Melt Distribution Coefficients. Acta Geologica Sinica, English Edition, 85, 164-174. https://doi.org/10.1111/j.1755-6724.2011.00387.x

[66] Hoskin, P.W.O., Kinny, P.D., Wyborn, D. and Chappell, B.W. (2000) Identifying Accessory Mineral Saturation during Differentiation in Granitoid Magmas: An Integrated Approach. Journal of Petrology, 41, 1365-1396. 
https://doi.org/10.1093/petrology/41.9.1365

[67] Yang, J.H., Cawood, P.A., Du, Y.S., Huang, H., Huang, H.W. and Tao, P. (2012) Large Igneous Province and Magmatic Arc Sourced Permian-Triassic Volcanogenic Sediments in China. Sedimentary Geology, 261-262, 120-131.

https://doi.org/10.1016/j.sedgeo.2012.03.018

[68] Ngamy Kanwa, A., Tchakounté, N.J., Nkoumbou, C., Owona, S., Tchouankoue, J.P. and Mvondo Ondoa, J. (2019) Petrology and Geochemistry of the Yoro-Yangben Pan-African Granitoid Intrusion in the Archaean Adamawa-Yade Crust (SW-Bafia, Cameroon). Journal of African Earth Sciences, 150, 401-414.

https://doi.org/10.1016/j.jafrearsci.2018.11.004

[69] Nzenti, J.P., Barbey, P. and Tchoua, F.M. (1999) Evolution crustale au Cameroun: Eléments pour un modèle géodynamique de l'orogenèse néoprotérozoïque. Géologie et environnements au Cameroun, collection GEOCAM, Vol. 2, 397-407. 